\title{
Coffea arabica L: History, phenology and climatic aptitude of the state of São Paulo, Brazil
}

\author{
Guilherme Almussa Leite Torres ${ }^{1}$ (D) https://orcid.org/0000-0001-7388-2508 \\ Cleide Nascimento Campos ${ }^{1}$ (D) https://orcid.org/0000-0002-5449-0709 \\ Marcus Vinicius Salomon² (D) https://orcid.org/0000-0002-0889-0090 \\ Angélica Prela Pantano3 (D) https://orcid.org/0000-0002-6509-1981 \\ Julieta Andrea Silva de Almeida ${ }^{1, *}$ (D) https://orcid.org/0000-0001-9569-4524 \\ 1. Instituto Agronômico de Campinas - Centro de Café - Campinas (SP), Brazil. \\ 2. Coordenadoria de Desenvolvimento Rural Sustentável - Gabinete do Coordenador - Campinas (SP), Brazil. \\ 3. Instituto Agronômico de Campinas - Centro de Ecofisiologia e Biofísica - Campinas (SP), Brazil. \\ *Corresponding author: julieta.almeida@sp.gov.br
}

\begin{abstract}
The genus Coffea belongs to the Rubiaceae family and includes two species with optimum economic performances, Coffea arabica and Coffea canephora. The state of São Paulo is one of the states that produce the species C. arabica in Brazil. Arabica coffee has been of great importance to São Paulo, providing relevant contributions to the historical, political, architectural, gastronomic, touristic, artistic, agricultural, industrial and social sectors since its introduction into the state in the nineteenth century. The agricultural sector includes crops produced by both small farmers and by highly technological agricultural groups. Coffea arabica plants present six phenological phases, all sensitive to changes in temperature and rainfall. In the reproductive phases, the species requires short days, low temperatures and no rainfall, followed by the rainy season. However, the phenological phases of the coffee plants can be harmed or even inhibited by dry or rainy seasons that are too long or too short. In the state of São Paulo, the municipalities of Garça and Franca show optimal coffee productivity, whereas those of Adamantina and Registro are low, and the agricultural aptitudes of these four municipalities show strong relationships with their geographical distributions in the state. Garça and Franca are situated in areas where the predominant dry and rainy seasons favor the occurrence of the phenological phases of arabica coffee plants, whereas Adamantina and Registro are located in areas with long dry and rainy seasons, respectively, characteristics that harm the development of the reproductive phenological phases of this culture.
\end{abstract}

Keywords: coffee; hydric balance; phenology; temperature; rainfall.

\section{INTRODUCTION}

In Brazil, coffee was first cultivated in the region of the city of Belém, in the state of Pará, and eventually arrived in São Paulo via the Paraíba Valley, from where it moved into the interior of the state at the beginning of the 19th century, coming from the region of Vassouras in the state of Rio de Janeiro (CARVALHO, 2007; NARITOMI et al., 2012).

The coffee culture spread rapidly, arriving in the center-west of the state of São Paulo, such that, as from the middle of the nineteenth century, coffee was the main commercial product in Brazil, at one time representing $3 / 4$ of the total value of exportations (CARVALHO, 2007). As it expanded, coffee consolidated itself as the basis of the economy of the country in the mid-nineteenth century and first decades of the twentieth century (SÃO PAULO, 2020), representing the great richness of the state of São Paulo and leading to the appearance of towns and large infrastructures such as railways, which roam the interior of the state up to the present day (Fig. 1). Thus, coffee reached regions further and further from the coast, which was possible due to the abundance of land with virgin soil. In this way, the railways appeared to help the existing coffee production, making the production transport to the port of Santos quicker, safer and cheaper (HOLLOWAY, 1984).

Received: Nov 29, 2020. Accepted: Nov 3, 2021

Associate Editor: Silvia Galleti

Peer Review History: Double-blind Peer Review. 


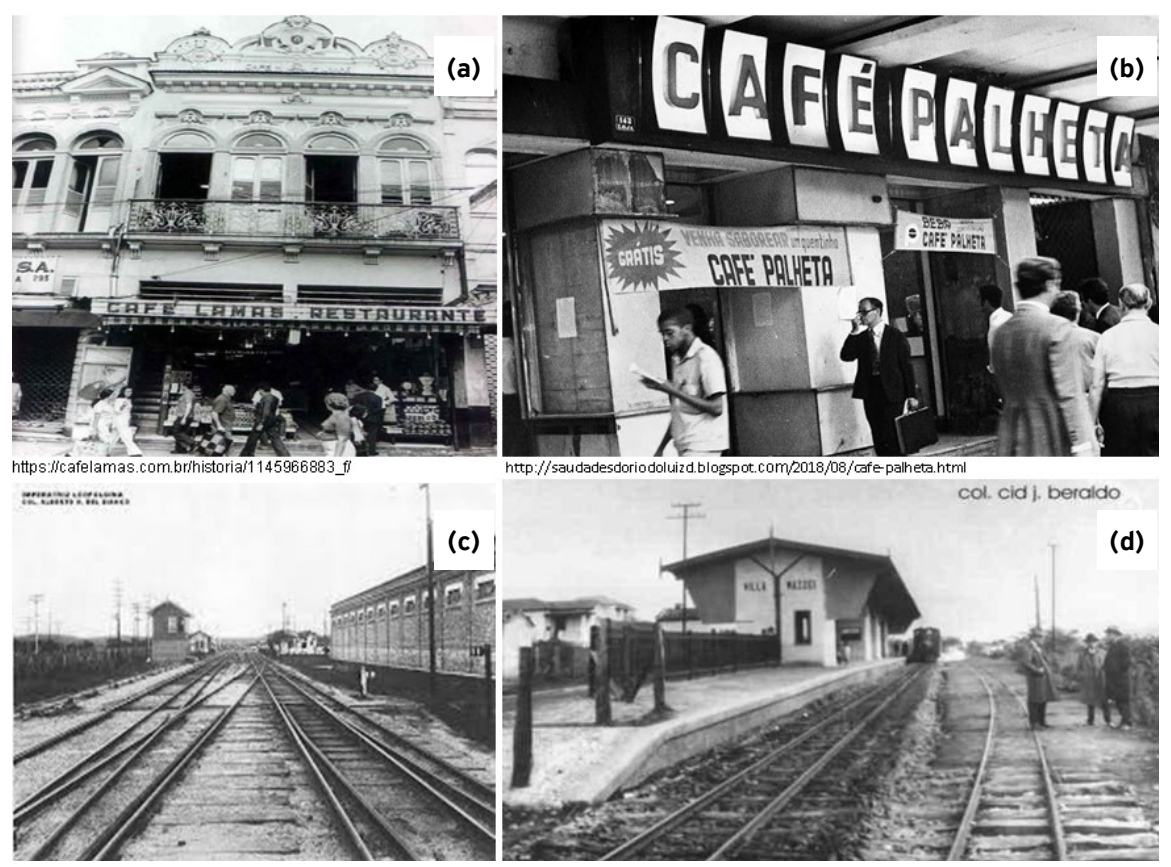

Figure 1. Scenes related to the period of introduction of coffee culture in the history of Brazil. Source: Images retrieved from Pinterest (a. https://pin.it/3bKyOOH; b. https://pin.it/2ijDFW5; c. https://pin.it/3a36SKU; d. https://pin. it/5504Fto).

The development of the state of São Paulo in 1880 was notable; commerce tripled, and the population grew considerably, the production of coffee in the state represented half of the entire coffee production in Brazil, and immigration presented significant results (CARVALHO, 2007). This glorious past still has territorial marks that can be seen today (Fig. 1a). The mansions, the railways and the train stations still have a symbolic presence in the landscape of various locations in the state (Fig. 1b-d). Another aspect that differs from the historic symbolism but is nevertheless an inheritance of the epoch is industrialization, which began to coincide with the great increase in coffee production and the marked arrival of European immigrants attracted by the production mentioned above (MAMIGONIAN, 1976). Today, São Paulo is still considered one of the largest industrial centers in Brazil.

Coffee production in Brazil has worldwide prominence, where diverse production systems as from small rural producers to highly technological systems covering extensive areas with favorable climates and soils, have made the country the largest producer and exporter of this raw material, making this national agricultural sector one of the most important segments of the Brazilian economy (MEIRELES et al., 2007). Considering its historical weight and economic relevance, studies of the climatic conditions aimed at understanding the climate's challenges on the coffee culture's development are of considerable importance to understand the natural production difficulties.

With the arrival of coffee in Brazil in the 18th century and its growing importance in the state of São Paulo at the beginning of the 19th century, an extensive bibliography was produced with the intuition of understanding the relationship between the climate and coffee plantations. These studies served as a basis for Brazilian science to make advances in improving the coffee culture at the end of the 20th century and the beginning of the 21th century, contributing to the Brazilian coffee culture becoming one of the most promising in the world.

\section{BOTANICAL DESCRIPTION}

Coffee belongs to the family Rubiaceae, subfamily Cinchonoideae and tribe Coffeae (CLIFFORD et al., 1989). Rubiaceae is the largest botanical family, with about 650 genera and 13,000 species of tropical and subtropical distribution (ROVA et al., 2002). The genus Coffea has about 103 species naturally occurring in tropical Africa (DAVIS et al., 2006). Of the species making up the genus Coffea, only two show worldwide economic importance: C. arabica known as arabica coffee and C. canephora known as robusta or conilon coffee (ECCARDI; SANDALJ, 2004; DAVIS et al., 2006; VEGA, 2008).

According to CARVALHO (2008), these species are of different origins. Coffea arabica originated in the southwest of Ethiopia in tropical forests, in the southeast of Sudan and the north of Kenya, at altitudes between 1,000 and 2,000 m, with 
mild climates. On the other hand, C. canephora originated from Guinea to Congo, in tropical forests in the lower Congo, from the west coast to the central region of the African continent, at low altitudes and annual rainfalls between 1,500 and 2,000 mm (ECCARDI; SANDALJ, 2004). These two coffee species differ from one another in diverse aspects: C. arabica produces beans which beverage is classified as being of good quality or "filter coffee" since it has low caffeine contents (Fig. 2), whereas C. canephora is the raw material used to produce soluble coffees since its beans contain high caffeine and acid contents, making its beverage "hard" to the palate (LEROY et al. 2006; FOLMER, 2017). Coffee is one of the most important cultures in the world economic scenario, standing out as the second most commercialized commodity globally and the fifth most commercialized agricultural product in Brazil (CONAB, 2015).

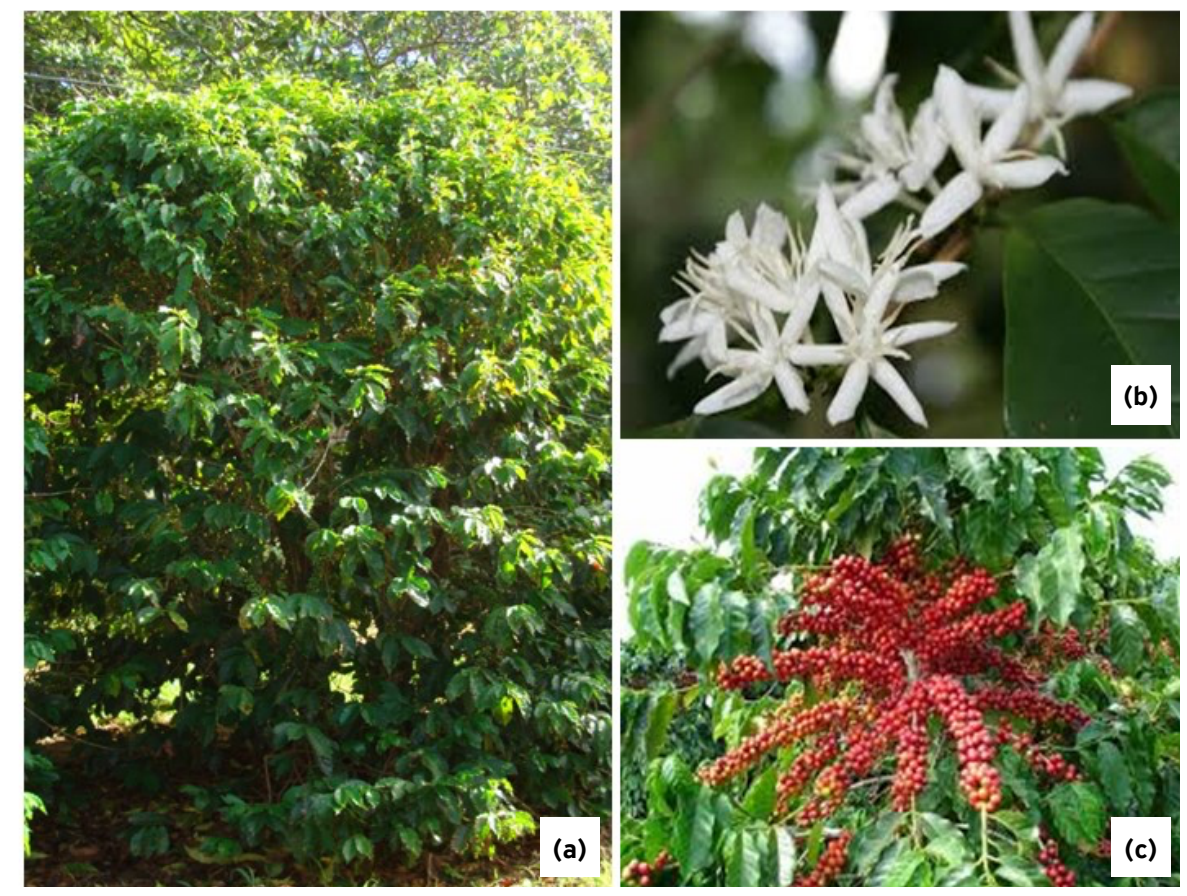

Figure 2. Example of a plant of Coffee arabica (a) with details of flowers (b) and branches with fruits (c). Source: Elaborated by the authors.

\section{PHENOLOGY OF Coffea arabica}

One must consider the plant's phenology to understand the coffee plant's growth and development responses when faced with the influences of climatic factors. The arabica-type coffee plant is a perennial woody bush with an extremely complex phenological cycle (CARVALHO, 2008).

This species' vegetative and reproductive phases occur simultaneously, and the flowering and fruiting phases occur in a two-year cycle, different from other species that complete their phenological cycle in the same year (MAJEROWICZ; SONDAHL, 2005).

It should be pointed out that the reproductive phases of the coffee plant consist of the development of the flower bud, flowering, fruiting and ripening (MORAIS et al., 2008). According to PEZZOPANE et al. (2003), C. arabica plants complete their production cycle in two years, with the vegetative and floral stages occurring in the first year and fruit production in the next characterizing the species as biannual. CAMARGO; CAMARGO (2001) established a didactic six development phase phenological scale for the arabica plants to complete their reproductive cycle (Fig. 3).

According to this scale, vegetative growth occurs from September of year 1 to March of year 2, characterized by long days, corresponding to phase 1. In the next phase, from April to August, with shorter days, the reduction in the photoperiod acts as a signal for floral induction, leading to the transition of the vegetative axillary buds into reproductive ones for floral induction, corresponding to phase 2. The perception of this stimulus is called floral evocation, and its morphophysiological alterations produce the floral beginnings. The months of July and August (phase 2) correspond to the dry season, with an absence of rainfall, and hence the coffee plants show bud dormancy, ceasing to grow and remaining at rest, an event highly characteristic and peculiar to the flowering of C. arabica. The rainy season occurs soon after, 
from September to December leading to the renewal of growth and development of the floral buds (CANNELL, 1985). The hydric potential of the plants becomes less negative, leading to the interruption of the bud dormancy initiated in the first phase of the 2nd phenological year and the end of the flowering phase of the 1st phenological year, this being phase 3. Anthesis, or floral opening, occurs in this period. The flowers are then fertilized, starting the fruit growth phase, corresponding to phase 4 (CAMARGO; CAMARGO, 2001; KUMAR, 1979; REIS; CUNHA, 2010). The fruits develop slowly from September to March, a process characterized by successive divisions and elongation of the perisperm and endosperm, giving origin to the coffee pellets and fruit expansion. In sequence, the fruit liquids solidify, giving rise to the beans. The last phase of reproductive development, or maturation, occurs at the end of this process, corresponding to phase 5 (CAMARGO; CAMARGO, 2001; MORAIS et al., 2008). Finally, the coffee plant rests after harvesting the ripe fruits, accompanied by branch senescence, corresponding to phase 6 .

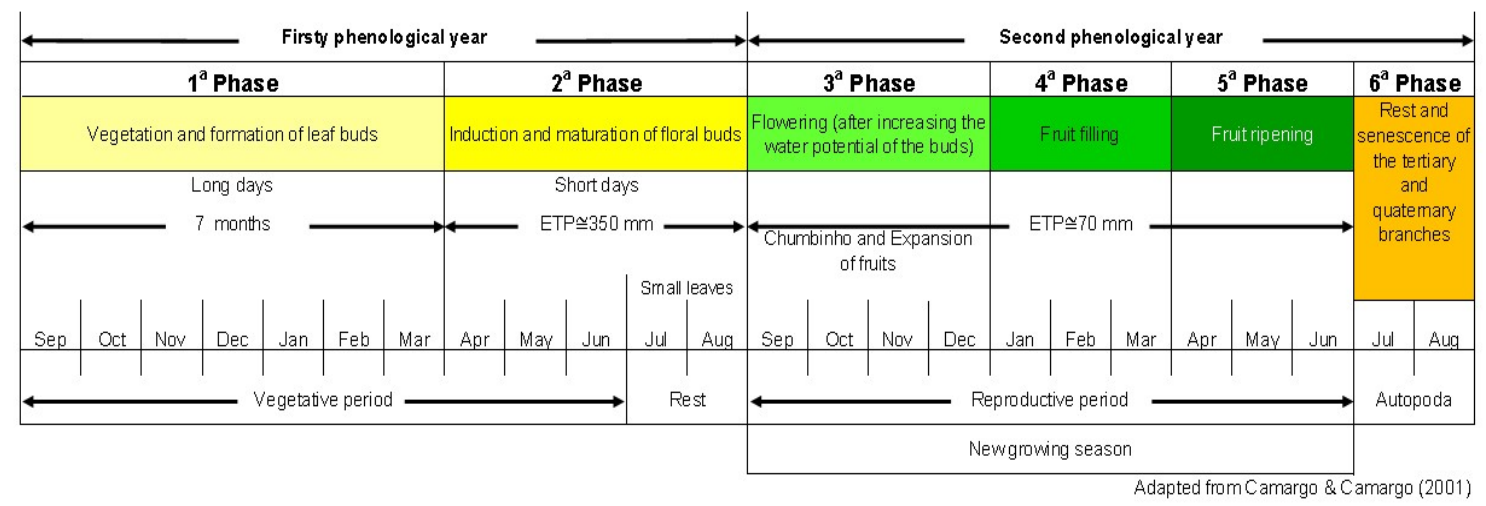

Figure 3. Phenological phases of the species Coffee arabica. Source: Retrieved from CAMARGO; CAMARGO (2001).

\section{CLIMATIC CONDITIONS VS COFFEE CULTURE}

Climate changes are related to changes in temperature and rainfall, which can be attributed to anthropogenic action or natural causes (CERRI et al., 2007; SILVA; PAULA, 2009). The global heating rate is unequal due to the effect of the oceans, which absorb about $92 \%$ of the sun's energy and move it by way of horizontal and vertical currents. There may well be many more years during which the mean environmental temperature does not rise significantly. Distant regions may even experience colder seasons as seasonal winds change and cause heating in other parts of the world (SILVA; PAULA, 2009).

Climate changes have caused harmful effects in various sectors of the environment, such as agriculture (PHAM et al., 2019). The influence of this phenomenon in agriculture has shown an expressive impact since it harms both aspects of the production of the culture and also social aspects, as reflected by those involved in this activity, whose subsistence is associated with the activity since the coffee production englobes various professionals who work in different links of the chain. According to RODRIGUES et al. (2014), the climate is considered the main factor influencing the productive performance of plants, and consequently, the production costs. The main effects of climate change on agriculture are increases in variability, decreases in production in certain areas and changes in geography (CANAL-DAZA; ANDRADE-CASTAÑEDA, 2019; EBRAHIMI-KHUSFI et al., 2020).

Water availability significantly influences the phenological cycle of arabica-type coffee plants (CHESEREK; GICHIMU, 2012; TESFAYE et al., 2013). From October to March, arabica coffee plants require at least $150 \mathrm{~mm}$ of rainfall per month to trigger flowering, fruit formation, and new branches' budding. The coffee plant demands more water during this period but, as a counterpart, is less demanding during the phases of harvesting and resting, between June and September, the months which correspond to the dry season (MATIELLO, 1991). Thus, the complex phases of flowering and growth (Fig. 3) are benefited by the hydric availability in the rainy season, and those of ripening and harvesting by the hydric deficiency of the dry season. Coffee plants require a quantity of about 1,200 $\mathrm{mm}$ of annual rainfall for their satisfactory growth and development. Hydric deficiencies of below $150 \mathrm{~mm}$ together with temperatures above $23^{\circ} \mathrm{C}$ are extremely harmful to their growth since they are considered inadequate for coffee plants due to restrictions on fruiting, hence reducing productivity (MATIELLO, 1991). 
The temperature factor can also be extremely restrictive for this culture (BARDIN-CAMPAROTTO et al., 2012). For example, temperatures above $28^{\circ} \mathrm{C}$ reduce leaf production and photosynthetic activity, and temperatures above $34^{\circ} \mathrm{C}$ favor floral abortion, considerably reducing productivity (CAMARGO, 1985; PILAU; ANGELOCCI, 2016). Each coffee plant developmental event has an ideal temperature for its occurrence (SILVA; MAZZAFERA, 2008). Another highly important factor for coffee plants is altitude, which strongly impacts $C$. arabica beverage quality. This species performs best when cultivated at high altitudes, and low altitudes are detrimental to beverage quality (SILVA et al., 2016; SILVEIRA et al., 2016).

Considering these edaphoclimatic conditions, the coffee plant figures as a species that requires specific needs to be productive and profitable for the farmer; it is not a culture that can be cultivated under variable environmental conditions. Various climatic factors interfere with the physiological development of coffee plants. The climatic elements can figure as favorable or unfavorable to the development of flowering and consequently of fruiting. The phenological phases and the final beverage quality are directly influenced by the meteorological conditions, mainly by the hydric availability, temperature and photoperiodic variation.

Although the state of São Paulo is among the most productive Brazilian states with coffee, not all its geographical regions are apt for coffee production, considering its great territorial extension which provides diversification of climatic conditions. This difference in coffee production between the regions is due to the climatic demands made by the culture for its development to occur satisfactorily with adequate, economically feasible production. The inequality in coffee production in the state of São Paulo becomes didactically evident when comparing the climatic, geographical and productive conditions of the municipalities with high and low coffee plant production, such as those of Franca and Garça and Adamantina and Registro, respectively (Fig. 4).

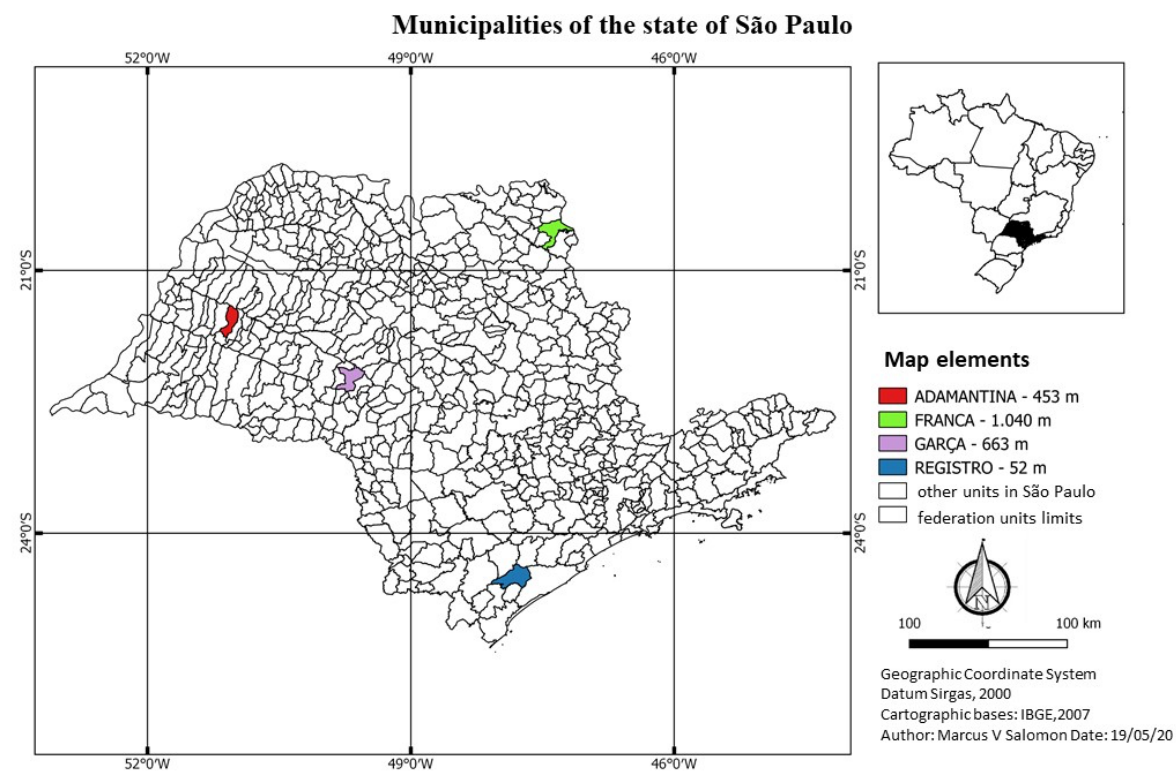

Figure 4. The geographic location of the municipalities of Adamantina, Franca, Garça and Registro of the state of São Paulo, Brazil. Source: Elaborated by the authors.

The climatic dynamics found in the areas studied conserve similarities and differences when their temperatures and rainfalls are analyzed. From these data, one can understand how the pluviometry of an area can sustain or otherwise, the ideal temperature and rainfall conditions for profitable production of arabica-type coffee plants.

Despite being located in distinct areas of the state of São Paulo, the municipalities studied show regional climatic conditions that mark their similarities, and can be clearly seen in the normal climatological temperatures (Fig. 5). In these municipalities, the small variations in normal climatological rainfalls are due to local physical aspects such as relief, coastline and continentality. The city of Adamantina is located in the region known as "Alta Paulista" (Fig. 4), and its climate is classified as Cwa, a tropical climate with mild, dry winters followed by very hot summers, at an altitude of $453 \mathrm{~m}$, the latitude of $21^{\circ} 41^{\prime} 07^{\prime \prime} \mathrm{S}$ and longitude of $51^{\circ} 04^{\prime} 21^{\prime \prime} \mathrm{W}$. The mean annual temperature is $22.9^{\circ} \mathrm{C}$, January being the hottest month with a mean of $25.4{ }^{\circ} \mathrm{C}$ and July the coldest, with a mean of $7.0^{\circ} \mathrm{C}$ (Fig. 5a). The rainfall is reduced from April to September, reaching greater volumes in the year's remaining months. 
(a)

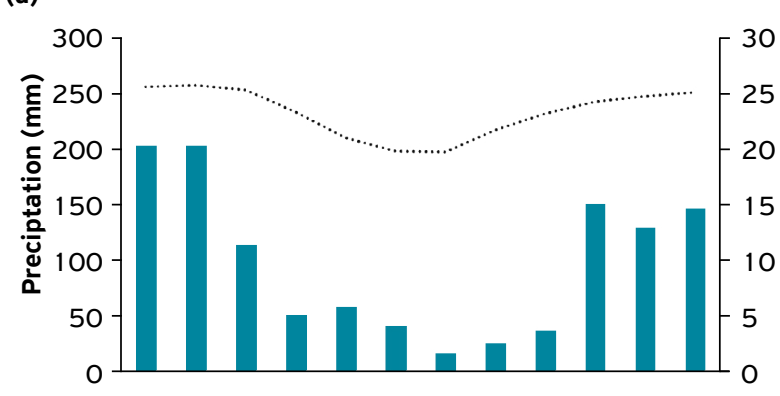

(c)

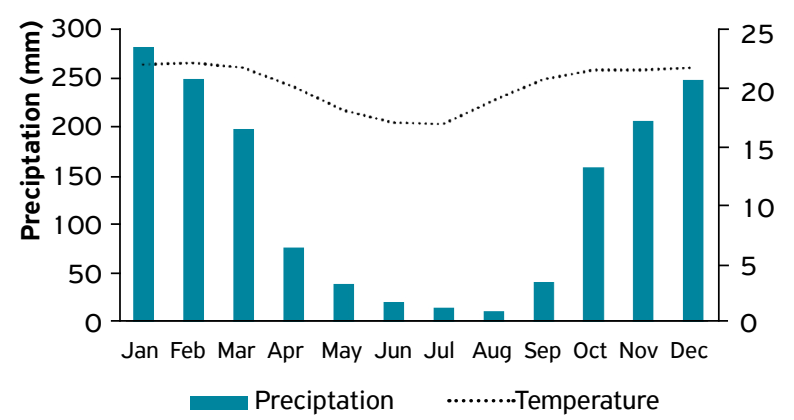

(b)

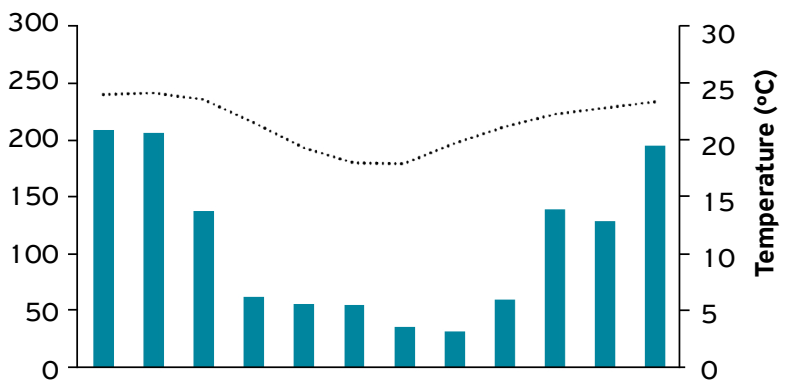

(d)

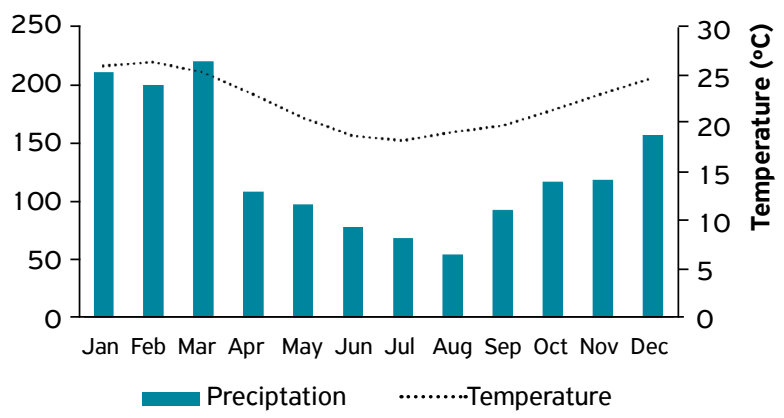

Figure 5. Average monthly rainfall and air temperature, normal climatological, for the municipalities of Adamantina (a), Garça (b), Franca (c) and Registro (d) of the state of São Paulo, Brazil

Source: Elaborated by the authors using data from Ciiagro (www.ciiagro.sp.gov.br).

The municipality of Garça is situated in the center-west of the state (Fig. 4) and has a climate classified as Cwa, subtropical, dry winters and hot summers, altitude of $663 \mathrm{~m}$, latitude of $22^{\circ} 12^{\prime} 39^{\prime \prime} \mathrm{S}$ and longitude of $49^{\circ} 39^{\prime} 21^{\prime \prime} \mathrm{W}$. The maximum temperature occurs in January with a monthly mean of $28.5^{\circ} \mathrm{C}$, and the minimum in July with a monthly mean of $17.8^{\circ} \mathrm{C}$ (Fig. 5b). The hottest period occurs from December to March, with temperatures varying from 25 to $30^{\circ} \mathrm{C}$, coinciding with the heaviest rainfalls of the year, and the mildest temperatures occur from April to July. The municipality of Franca is situated on a highland plateau, also known as "Alta Mogiana" (Fig. 4), at an altitude of 1,040 m, latitude of 20³2'20'S and longitude of $47^{\circ} 24^{\prime} 03^{\prime} \mathrm{W}$. Franca has dry winters from April to August. The rainy season starts in September, usually over $150 \mathrm{~mm}$, with summer rain between January and April and moderate temperatures throughout the year, with a mean annual temperature of $21^{\circ} \mathrm{C}$ (Fig. 5 c).

The municipality of Registro is situated in the region closest to the southern coastline of the state of São Paulo, at an altitude of $52 \mathrm{~m}$, latitude of $24^{\circ} 29^{\prime} 16^{\prime} \mathrm{S}$ and longitude of $47^{\circ} 50^{\prime} 38^{\prime} \mathrm{W}$ (Fig. 4), with a climate classified as moist subtropical (Cfa). This municipality has no dry season, with the four seasons characterized, with mild winters and hot, humid summers (Fig. 5d). The mean temperature of the coldest month (July) is $12.9^{\circ} \mathrm{C}$, and that of the hottest month (January), $27.8^{\circ} \mathrm{C}$. The rainfall throughout the year is usually above $100 \mathrm{~mm}$, with the greatest intensity from January to March. This type of climate is common along the coastline in the southwestern region of the state.

Due to the low altitude, flat relief, high density of the Atlantic Forest and proximity to the Atlantic Ocean, the temperatures tend to be higher than in other localities at the same latitude. In the hotter months of the year, even on cloudy days, the extreme sultriness raises the temperature in the region, causing a certain discomfort. In contrast, in the winter, the appearance of mist is common in the early morning, increasing the sensation of cold. This information infers that the arabica-type coffee culture's adequate climatic conditions are not found in all the locations studied.

The hydric balance presented in Figure 6 reflects the water availability in the four municipalities studied. The city of Adamantina shows a hydric deficit for an extended period during the year, mainly between March and October, with greater intensity between August and October (Fig. 5a) and significant rainfall between January and mid-March. Garça shows a hydric deficit for a shorter period, corresponding to July to October, with rainfall between mid-October and December and a greater rainfall intensity from January to April (Fig. 6b). Franca presents a similar hydric balance pattern to that of Garça, with a hydric deficit extending from April to October and rainfall in the other months, but with greater intensity from January to April (Fig. 6c). On the other hand, the municipality of Registro has rainfall throughout the entire year and the complete absence of hydric deficit (Fig. 6d). 
(a)

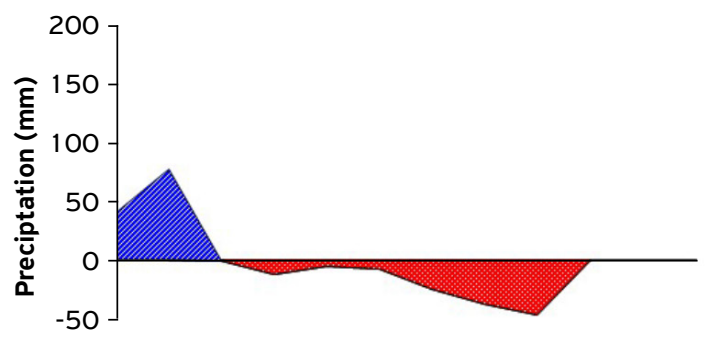

(c)

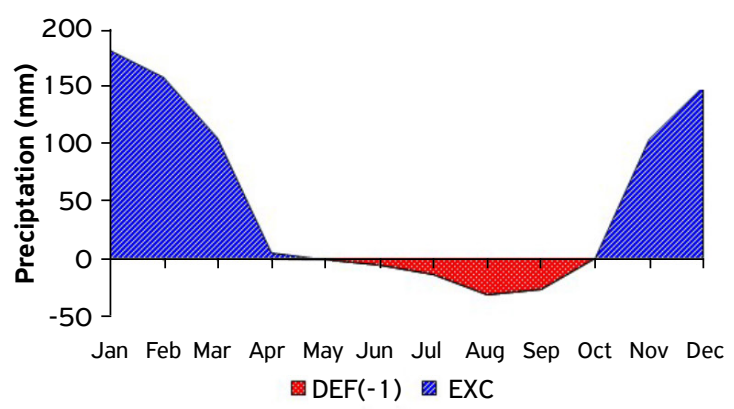

(b)

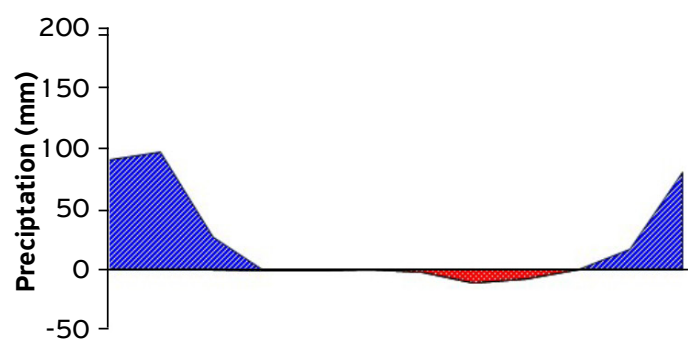

(d)

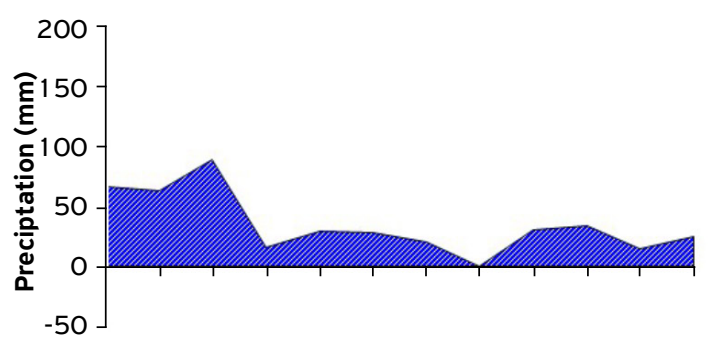

Jan Feb Mar Apr May Jun Jul Aug Sep Oct Nov Dec

圆 $\operatorname{DEF}(-1)$

Figure 6. Extract of water balance, normal climatological, for the municipalities of Adamantina (a), Garça (b), Franca (c) and Registro (d) of the state of São Paulo, Brazil. DEF.: Deficiency, EXC. Excess.

Source: Elaborated by the authors using data from Ciiagro (www.ciiagro.sp.gov.br).

\section{PHYSIOLOGICAL RESPONSES OF Coffea arabica TO THE CLIMATIC CONDITIONS}

The state of São Paulo contributes significantly to the production of arabica-type coffee, with an estimated 5.7 to 6.1 million sacks in 2020 (CONAB, 2020). However, the products within the state are not uniform, as evidenced didactically by the results for arabica type coffee production in the municipalities of Adamantina, Franca, Garça and Registro in the period between 2015 and 2019 (Fig. 7). In this period, it can be seen that the municipalities of Garça and Franca occupy extensive areas of coffee plantations in the state, whereas Adamantina and Registro show reduced areas of this culture. This panorama is confirmed by the data for the production of processed coffee, Garça and Franca showing an elevated production of processed beans, whereas this activity is of limited expression in Adamantina and Registro (Fig. 8).

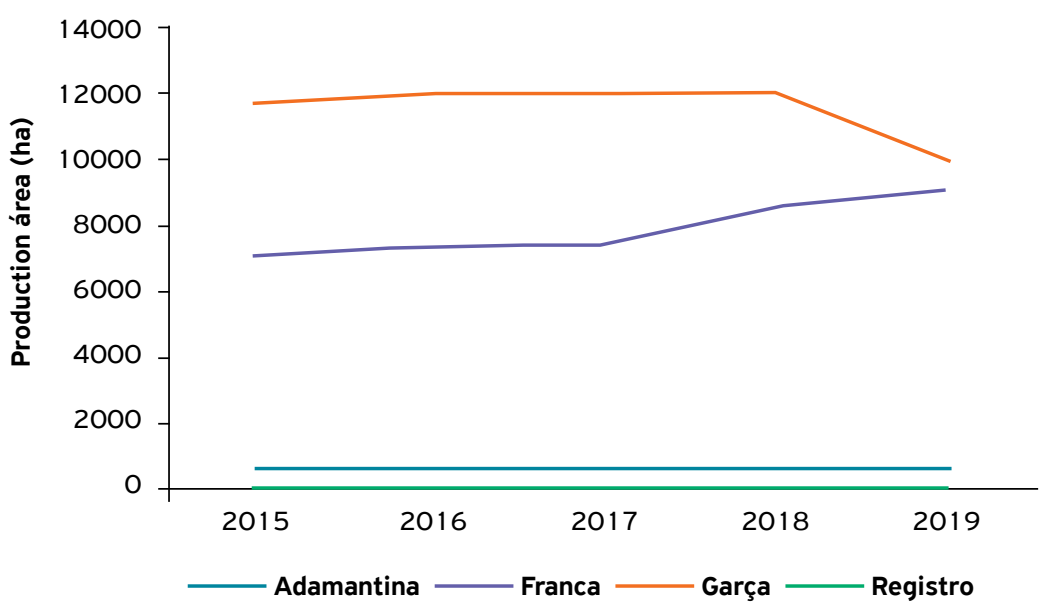

Figure 7. Area cultivated with Coffee Arabica in the municipalities of Adamantina, Franca, Garça and Registro, in the state of São Paulo, Brazil, from years 2015 to 2019.

Source: Elaborated by the authors using data from IEA - Instituto de Economia Agrícola (http://www.iea.sp.gov.br). 


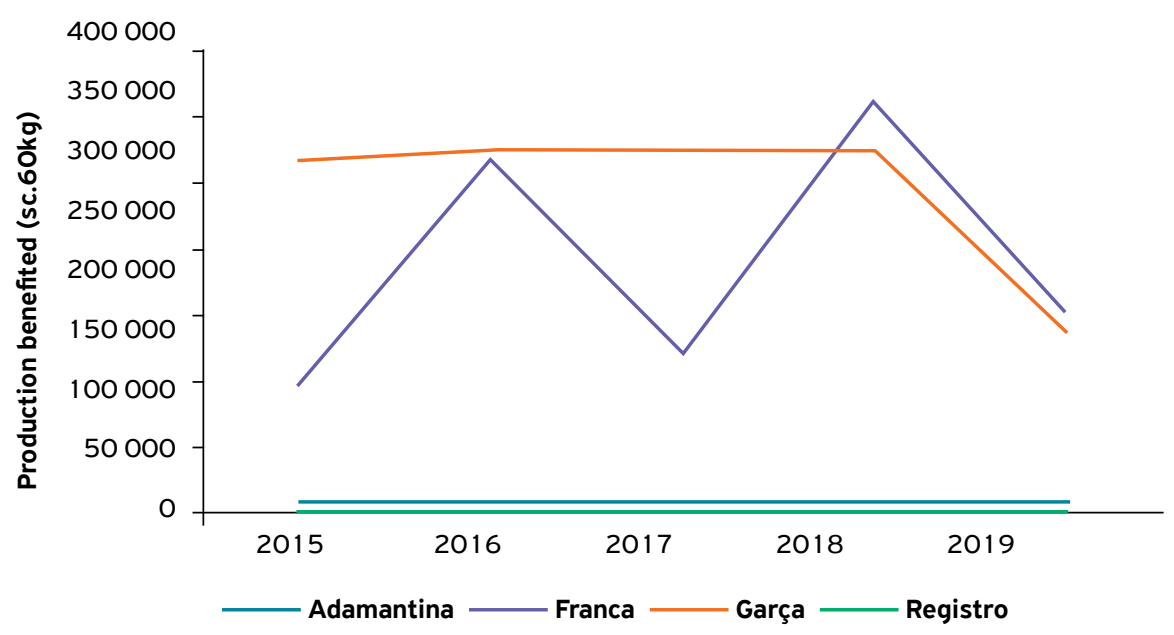

Figure 8. Coffee Arabica production benefited from Adamantina, Franca, Garça and Registro's municipalities in the state of São Paulo, Brazil, from years 2015 to 2019.

Source: Elaborated by the authors using data from IEA - Instituto de Economia Agrícola (http://www.iea.sp.gov.br).

The differences in the responses of the four municipalities with respect to the area of coffee plantations and the production of processed coffee have a close relationship with their geographical layouts (Fig. 4) and the differentiated climatic conditions that affect the phenological responses of the coffee plants (Fig. 3). The municipalities of Garça and Franca with their optimal responses for the production of processed coffee show regimes with mean temperatures of, respectively, 21 and $28.5^{\circ} \mathrm{C}$, and the availability of periods of high and low rainfall throughout the year, characteristics which favor the good development of the phenological phases of C. arabica plants.

Thus, Garça and Franca present a predominant dry season between April and September, followed by periods with a high frequency and intensity of rainfall between October and March (Figs. 5b and 5c). In these municipalities, the dry season occurs in the months corresponding to the phenological phases of the induction of vegetative buds in the floral buds when the reproductive phase starts (Fig. 3). In addition, all these characteristics agree with the observations of THOMAZIELLO et al. (2000) that the C. arabica culture shows good performance under favorable mean annual temperatures between 18 and $23{ }^{\circ} \mathrm{C}$ or ideally between 19 and $21^{\circ} \mathrm{C}$, with adequate mean annual rainfalls between 1,200 and $1,800 \mathrm{~mm}$ and altitudes between 4,400 and 1,200 m, the recommended altitudes for planting being between 600 and 1,200 $\mathrm{m}$. On the other hand, Adamantina and Registro present a different climatic pattern, which reduces or impedes coffee production, as can be seen, respectively, in Figures 5a, 5d and 6a, 6d. To allow for the commercial exploitation of the culture, it is important that the rainfall be distributed throughout the vegetative development and fruiting periods. According to PETEK et al. (2009), the combination between temperature and rainfall influences the determination of areas that are apt for this culture, since, if on the one hand hydric stress reduces the thermal needs of the plant, on the other hand, excess water demands a rise in temperature to complete the phenological stages, which are determinant in the productivity of the coffee plants. The moisture content should be neither high nor low for this culture since both propitiate pest propagation.

In another context, the municipality of Adamantina, with low production of processed coffee, has well-defined wet and dry seasons (Fig. 6a). However, in this case, the climatic conditions are adverse to the cultivation of C. arabica plants because the dry period is long, extending from March to October, and this low water availability harms the phenological phases of the induction of the floral bud and floral (Fig. 3). In addition, the mean temperature in Adamantina is above $22^{\circ} \mathrm{C}$ throughout the year (Fig. 5a), which also harms the development of the phenological phases of the arabica-type coffee plant.

These observations reinforce that the cultivation of arabica-type coffee plants requires specific climatic conditions, adequate for their development. A dry period of about three months is a fundamental condition for the induction of the floral bud in the coffee plant, followed by a rainy period to start anthesis, which cannot be too long or it will affect the fruiting phase, and must be accompanied by mild temperatures since high temperatures cause absorption of the flowers (CANAL-DAZA; ANDRADE-CASTAÑEDA, 2019). Coffee plants of the arabica species can withstand hydric deficits of up to $150 \mathrm{~mm}$ without much harm if they occur during the vegetative resting period, but in marginal regions, irrigation may be necessary (MESQUITA et al., 2016).

In situations where the lack of water is prolonged, depending on the developmental phase, the plants may die in the case of young plants, the flowers may abort, or the fruit filling out may be deficient, with a consequent reduction in production. The hydric availability influences the development of coffee fruits in the environment. Hydric deficiency accelerates the 
ripening of the arabica-type coffee fruits, which harms the development of the different physiological stages of seed formation and, subsequently, their germination capacity.

The municipality of Registro, which is also unproductive, is under the influence of climatic conditions that are completely unfavorable for developing of the phenological phases of arabica-type coffee plants. Rainfall is more frequent in this municipality and occurs in larger volumes throughout the year (Fig. 3d). Registro has no dry season (Fig. 6d) which is necessary to develop the phenological phases of floral bud and floral induction. These climatic characteristics harm the phenological phases of the arabica-type coffee plants, which explains the low production level of coffee processed in Registro (Fig. 8).

The water factor, both in excess and in reduced amounts, significantly affects coffee plants' developmental stages distinctly. Excessive rainfall causes damage to the bushes, the fall of fruit if close to harvest and can reduce flowering, affecting fruiting and the photosynthetic rate due to nebulosity. Intermittent rains throughout the year induce flowering outside the breeding season, which harms coffee production.

Although considered ideal, these conditions are not so, since, considering that this is a culture developed in the tropics, it is subject to all kinds of changes and the intemperate tropical climate occurring in Brazil. Hence, the production of the C. arabica plants is harmed when climate changes such as storms, strong winds and especially changes in the temperature and rainfall patterns occur.

\section{CONCLUSIONS}

The Arabic coffee culture has significantly influenced the history of the state of São Paulo and favored aspects of its economic, cultural and social development.

Coffea arabica is a perennial species presenting phenological phases strongly influenced by climatic conditions, principally by temperature and rainfall.

The municipalities of Garça and Franca in Brazil present optimal coffee production since they are geographically situated in regions of the state of São Paulo with climatic conditions showing the periodic presence and absence of rainfall and temperatures that favor good development of the phenological phases of the coffee plant.

The municipalities of Adamantina and Registro in the state of São Paulo present a limited production of coffee, since the climatic conditions of these regions harm the reproductive phases of the coffee plants due to an extensive dry season in the case of Adamantina and rainfall throughout the whole year in the case of Registro.

Climate changes, principally in terms of pluviometry resulting from natural and anthropogenic actions, can alter the productive capacity of $C$. arabica plants.

The pluviometric characteristics significantly influence the phenological phases of coffee plants, which directly affects their productive and economic potential.

\section{AUTHORS' CONTRIBUTIONS}

All authors had the idea for the article, performed the literature search and data analysis, and drafted the work.

AVAILABILITY OF DATA AND MATERIAL

Data sharing not applicable to this article as no datasets were generated or analyzed during the current study.

\section{FUNDING}

This work did not receive any specific grant from funding agencies in the public, commercial, or not-for-profit sectors.

\section{CONFLICTS OF INTEREST}

All authors declare that they have no conflict of interest.

ETHICAL APPROVAL

Not applicable.

\section{ACKNOWLEDGEMENTS}

This work was supported by Conselho Nacional de Desenvolvimento Científico e Tecnológico (CNPq), with the scientific initiation scholarship of the Programa Institucional de Iniciação Científica/PIBIC and Consórcio Brasileiro de Pesquisa Café. 


\section{REFERENCES}

BARDIN-CAMPAROTTO, L.; CAMARGO, M.B.P.; MORAES, J.F.L. Época provável de maturação para diferentes cultivares de café arábica para o Estado de São Paulo. Ciência Rural, Santa Maria, v.42, n.4, p.594-599, 2012. https://doi.org/10.1590/S0103-84782012000400003

CAMARGO, A.P. Florescimento e frutificação de café arábica nas diferentes regiões (cafeeiras) do Brasil. Pesquisa Agropecuária Brasileira, Brasília, v.20, n.7, p.831-839, 1985. Available from: https://seer.sct.embrapa.br/index.php/pab/article/view/15819. Access on: 22 June. 2020.

CAMARGO, A.P.; CAMARGO, M.B.P. Definição e esquematização das fases fenológicas do cafeeiro arábica nas condições tropicais do Brasil. Bragantia, Campinas, v.60, n.1, p.65-68, 2001. https://doi.org/10.1590/S0006-87052001000100008

CANAL-DAZA, D.; ANDRADE-CASTAÑEDA, H. Adaptation to climate change in coffee production systems in Tolima. Floresta Ambiental, Seropédica, v.26, n.3, e20171165, 2019. https://doi.org/10.1590/2179-8087.116517

CANNELL, M.G.R. Physiology of the coffee crop. In: CLIFFORD, M.N.; WILLSON, K.C. (Ed.). Coffee. Boston: Springer, 1985. p.108-134. https://doi.org/10.1007/978-1-4615-6657-1_5

CARVALHO, D.F. Café, ferrovias e crescimento populacional: O florescimento da região noroeste paulista. Revista Histórica Online do Arquivo Público do Estado de São Paulo, São Paulo, v.27, p.10-16, 2007. Available from: http://www.arquivoestado.sp.gov.br/site/assets/ publicacao/anexo/historica27.pdf\#page=11. Access on: 14 May 2020.

CARVALHO, C.H.S. Cultivares de café: Origem, características e recomendações. Brasília: Embrapa Café, 2008. 334p.

CERRI, C.E.P.; SPAROVEK, G.; BERNOUX, M.; EASTERLING, W.E.; MELILLO, J.M.; CERRI, C.C. Tropical agriculture and global warming: Impacts and mitigation options. Science Agricola, Piracicaba, v.64, n.1, p.83-99, 2007. https://doi.org/10.1590/S0103-90162007000100013

CHESEREK, J.J., GICHIMU, B.M. Drought and heat tolerance in coffee: A review. International Research Journal of Agricultural Science and Soil Science, v.2, n.12, p.498-501, 2012. Available from: https://www.interesjournals.org/articles/drought-and-heat-tolerance-incoffee-a-review.pdf. Access on: 22 June 2020.

CLIFFORD, M.N.; WILLIAMS, T.; BRIDSON, D. Chlorogenic acids and caffeine as possible taxonomic criteria in Coffea and Psilanthus. Phytochemistry, Nantes, v.28, n.3, p.829-838, 1989. https://doi.org/10.1016/0031-9422(89)80124-4

CONAB - Companhia Nacional de Abastecimento. Acompanhamento da Safra Brasileira: Café-Safra 2015. Brasília: Conab, 2015. Available from: https://www.conab.gov.br/info-agro/safras/cafe/boletim-da-safra-de-cafe/item/download/1180_8e9cae8899f2dd46004 8b00c5b67ff08. Access on: 20 Mar. 2020.

CONAB - Companhia Nacional de Abastecimento. Acompanhamento da Safra Brasileira: Café-Safra 2015. Brasília: Conab, 2020. Available from: https://www.conab.gov.br/info-agro/safras/cafe/boletim-da-safra-de-cafe/item/download/30380_d1elf36c2356b81e8a385cd24f05993b. Access on: 30 Mar. 2020.

DAVIS, A.P.; GOVAERTS, R.; BRIDSON, D.M.; STOFFELEN, P. An annotated taxonomic conspectus of the genus Coffea (Rubiaceae). Botanical Journal Linnean Society, Oxford, v.152, n.4, p.465-512, 2006. https://doi.org/10.1111/j.1095-8339.2006.00584.x

EBRAHIMI-KHUSFI, Z;; MIRAKBARI, M.; KHOSROSHAHI, M. Vegetation response to changes in temperature, rainfall, and dust in arid environments. Environmental Monitoring Assessment, Dordrecht, v.192, n.691, 2020. https://doi.org/10.1007/s10661-020-08644-0

ECCARDI, F.; SANDALJ, V. O café: Ambientes e diversidade. São Paulo: Casa da Palavra, 2004. 256p.

FISCHERSWORRING, B.; SCHMIDT, G.; LINNE, K.; LINE, G.; PRINGLE, P.; BAKER, P.S. Climate change adaptation in coffee production: A step-by-step guide to supporting coffee farmers in adapting to climate change. Hamburg: Coffee and Climate. 184p. 2015. Available from: https://toolbox.coffeeandclimate.org/\%20wp-content/uploads/2012/10/cc-step-by-step-guide-for-climate-change-adaptation-incoffee-production.pdf. Access on: 10 July 2020

FOLMER, B. The craft and science of coffee. Cambridge: Academic Press, 2017. 556p. 
HOLLOWAY, T.H. Imigrantes para o café: Café e sociedade em São Paulo, 1886-1934. Rio de Janeiro: Paz e Terra, 1984. 298p.

KUMAR, D. Some aspects of the physiology of Coffea arabica L: A review. Kenya Coffee, Nairobi, v.44, n.519, p.9-47, 1979.

LEROY, T.; RIBEYRE, F.; BERTRAND, B.; CHARMETANT, P.; DUFOUR, M.; MONTAGNON, C.; MARRACCINI, P.; POT, D. Genetics of coffee quality. Brazilian Journal Plant Physiology, Londrina, v.18, n.1, p.229-242, 2006. https://doi.org/10.1590/S1677-04202006000100016

MAJEROWICZ, N.; SONDAHL, M.R. Induction and differentiation of reproductive buds in Coffea arabica L. Brazilian Journal Plant Physiology, Londrina, v.17, n.2, p.247-254, 2005. https://doi.org/10.1590/S1677-04202005000200008

MAMIGONIAN, A.O. Processo de industrialização em São Paulo. Boletim Paulista de Geografia, São Paulo, v.50, p.83-100, 1976. Available from: https://publicacoes.agb.org.br/index.php/boletim-paulista/article/view/1123/984. Access on: 10 Apr. 2020.

MATIELLO, J.B. O café: Do cultivo ao consumo. São Paulo: Globo, 1991. 320p.

MEIRELES, E.J.L.; VOLPATO, M.M.L.; ALVES, H.M.R.; VIEIRA, T.G.C. Zoneamento agroclimático: Um estudo de caso para o café. Informe Agropecuário, Belo Horizonte, v.28, n.241, p.50-57, 2007. Available from: http://epamig.ufla.br/geosolos/publicacoes/2007/11. pdf. Access on: 15 July 2020.

MESQUITA, C.M.; MELO, E.M.; REZENDE, J.E.; CARVALHO, J.S.; FABRI JÚNIOR, M.A.; MORAES, N.C.; DIAS, P.T.; CARVALHO, R.M.; ARAÚJO, W.G. Manual do café: Implantação de cafezais (Coffea arabica L). Belo Horizonte: EMATER-MG, 2016. 50p.

MORAIS, H.; CARAMORI, P.H.; KOGUISHI, M.S.; RIBEIRO, A.M.A. Escala fenológica detalhada da fase reprodutiva de Coffea arabica. Bragantia, Campinas, 67, n.1, p.257-260, 2008. https://doi.org/10.1590/S0006-87052008000100031

NARITOMI, J.; SOARES, R.R.; ASSUNÇÃO, J.J. Institutional development and colonial heritage within Brazil. The Journal of Economic History, Cambridge, v.72, n.2, p.393-422, 2012. https://doi.org/10.1017/S0022050712000071

PETEK, M.R.; SERA, T.; FONSECA, I.C.B. Exigências climáticas para o desenvolvimento e maturação dos frutos de cultivares de Coffea arabica. Bragantia, Campinas, v.68, n.1, p.169-181, 2009. https://doi.org/10.1590/S0006-87052009000100018

PEZZOPANE, J.R.M.; PEDRO JÚNIOR, M.J.P.; THOMAZIELLO, R.A.; CAMARGO, M.B.P. Escala para avaliação de estádios fenológicos do cafeeiro arábica. Bragantia, Campinas, v.62, n.3, p.499-505, 2003. https://doi.org/10.1590/S0006-87052003000300015

PHAM, Y.; REARDON-SMITH, K.; MUSHTAQ, S.; COCKFIELD, G. The impact of climate change and variability on coffee production: A systematic review. Climatic Change, Basingstoke, n.156, p.609-630, 2019. https://doi.org/10.1007/s10584-019-02538-y

PILAU, F.G.; ANGELOCCI, L.R. Padrões de interceptação de radiação solar por cafeeiros em função da área foliar. Coffee Science, Lavras, v.11, n.1, p.127-136, 2016. Available from: http://www.coffeescience.ufla.br/index.php/Coffeescience/article/view/1016/pdf_14. Access on:20 Aug. 2020.

REIS, P.R.; CUNHA, R.L. Café arábica: Do plantio à colheita. Lavras: EPAMIG, 2010. 896p.

RODRIGUES, N.A.; REIS, E.A.; TAVARES, M. Influências dos fatores climáticos no custo de produção do café arábica. Custos e @gronegócio on line, Recife, v.10, n.3, p.216-255, 2014. Available from: http://www.custoseagronegocioonline.com.br/numero3v10/Artigo\%2011\%20 clima.pdf. Access on: 14 Sept. 2020.

ROVA, J.H.E.; DELPRETE, P.G.; ANDERSSON, L.; ALBERT, V.A. A trnL-F cpDNA sequence study of the Condamineeae-RondeletieaeSipaneeae complex with implications on the phylogeny of the Rubiaceae. American Journal of Botany, San Luis, v.89, n.1, p.145-159, 2002. https://doi.org/10.3732/ajb.89.1.145

SÃO PAULO. O Café e a história da cidade. São Paulo: São Paulo, 2020. Available from: http://www.capital.sp.gov.br/cidadao/cultura/ roteiros-tematicos/o-cafe-e-a-historia-da-cidade. Access on: 20 Nov. 2020.

SILVA, E.A.; MAZZAFERA, P. Influence of temperature and water on coffee culture. The Americas Journal of Plant Science and Biotechnology, Kagawa, v.2, p.32-41, 2008. Available from: http://www.globalsciencebooks.info/Online/GSBOnline/images/0812/AmJPSB_2(1\&2)/ AmJPSB_2(2)32-41o.pdf. Access on: 17 Nov. 2020. 
SILVA, R.W.C.; PAULA, B.L. Causa do aquecimento global: Antropogênica versus natural. Terrae Didática, Campinas, v.5, n.1, p.42-49, 2009. https://doi.org/10.20396/td.v5i1.8637501

SILVA, S.A.; QUEIROZ, D.M.; FERREIRA, W.P.M.; CORRÊA, P.C.; RUFINO, J.L.S. Mapping the potential beverage quality of coffee produced in the Zona da Mata, Minas Gerais, Brazil. Journal of the Science Food Agriculture, Manhattan, v.96, n.9, p.3098-3108, 2016. https://doi.org/10.1002/jsfa.7485

SILVEIRA, A.S.; PINHEIRO, A.C.T.; FERREIRA, W.P.M.; SILVA, L.J.; RUFINO, J.L.S.; SAKIYAMA, N.S. Sensory analysis of specialty coffee from different environmental conditions in the region of Matas de Minas, Minas Gerais, Brazil. Revista Ceres, Viçosa, v.63, n.4, p.436-443, 2016. https://doi.org/10.1590/0034-737X201663040002

TESFAYE, S.G.; ISMAIL, M.R.; KAUSAR, H.; MARZIAH, M.; RAMLAN, M.F. Plant water relations, crop yield and quality in coffee (Coffea arabica L.) as influenced by partial root zone drying and deficit irrigation. Australian Journal of Crop Science, Lismore, v.7, n.9, p.1361-1368, 2013. Available from: https://search.informit.org/doi/abs/10.3316/informit.619623382235059. Access on: 2 Mar. 2021.

THOMAZIELLO, R.A.; FAZUOLI, L.C.; PEZZOPANE, J.R.M.; FAHL, J.I.; CARELLI, M.L.C. Café arábica: Cultura e técnicas de produção (Boletim técnico n. 187). Campinas: IAC, 2000. Available from: http://www.sidalc.net/cgi-bin/wxis.exe/?IsisScript=orton.xis\&method= post\&formato=2\&cantidad $=1$ \&expresion $=\mathrm{mfn}=048465$. Access on: 2 Mar. 2020.

VEGA, F.E. The rise of coffee: From humble origins in Africa, this plant's flavorful seeds started as a botanical curiosity and expanded to a worldwide staple. American Scientist, Morrisville, v.96, n.2, p.138-145, 2008. Available from: http://www.jstor.org/stable/27859121. Access on: 28 Nov. 2020. 